Ignacy Jóźwiak

e-mail: i.jozwiak@uw.edu.pl

Ośrodek Badań nad Migracjami UW

ORCID: 0000-0003-0143-6845

\section{Monika Szewczyk}

e-mail: m.szewczyk19@uw.edu.pl

Ośrodek Badań nad Migracjami UW

Szkoła Doktorska Nauk Społecznych

Uniwersytet Jagielloński

ORCID: 0000-0002-2797-0176
Sonia Styrkacz

e-mail: sonia.styrkacz@gmail.com

Ośrodek Badań nad Migracjami UW

Instytut Studiów Społecznych UW

ORCID: 0000-0002-4420-5476

\section{Elżbieta Mirga-Wójtowicz}

e-mail: e.mirga-wojtow@uw.edu.pl

Ośrodek Badań nad Migracjami UW

Wydział Politologii

Uniwersytet Pedagogiczny w Krakowie

ORCID: 0000-0002-3215-7825

\title{
KEEP CALM AND BESHEN KHERE . INTERNET I TRANSNARODOWA INTENSYFIKACJA ŻYCIA POLSKICH ROMÓW W CZASIE PANDEMII COVID-19
}

\section{Keep calm and beshen khere. Internet and transnational intensification of life among Polish Roma under the COVID-19 pandemic}

Streszczenie: Artykuł podejmuje, nieobecną do tej pory w polskich badaniach romologicznych, tematykę internetowych (rodzinnych i towarzyskich) praktyk polskich Romów. Głównego kontekstu dostarcza pandemia koronawirusa (COVID-19), towarzyszący jej stan zamknięcia (lockdown) i konieczność zachowania tzw. dystansu społecznego w okresie od połowy marca do końca kwietnia 2020 roku. Badania przeprowadzone zostały online wśród polskich Romów w Polsce i za granicą. Internet stanowi dla nas źródło informacji oraz możliwość kontaktu z uczestnikami badania.

\footnotetext{
${ }^{1}$ Tytuł artykułu zainspirowany został grafiką rozpowszechnioną przez jedną z międzynarodowych organizacji romskich. Jest to językowa hybryda, często obecna także w wypowiedziach polskich Romów w Internecie. Keep calm nawiązuje do popularnego obecnie i parafrazowanego hasła kierowanego do Brytyjczyków podczas II wojny (keep calm and carry on - 'zachowaj spokój i rób swoje' ), zaś beshen khere oznacza po romsku 'zostań w domu'.
} 
Ignacy Jóźwiak, Elżbieta Mirga-Wójtowicz, Sonia Styrkacz, Monika Szewczyk

Wskazujemy tym samym na specyfikę internetowych treści generowanych przez Romów, zarówno przed pandemią, jak i w jej trakcie. W tym obszarze zwracamy uwagę na zjawisko „wpasowywania się” kultury romskiej i związanego z nią prawa zwyczajowego w Internet i media społecznościowe. Na tym gruncie wprowadzamy pojęcie e-romanipen oznaczające przeniesienie kultury romskiej w przestrzeń online. Internetową aktywność w czasie pandemii interpretujemy jako przejaw kolektywnej sprawczości i kreatywności w działaniach na rzecz spójności grupy w sytuacji zagrożenia.

Słowa kluczowe: koronawirus (COVID-19), pandemia, migracje, media społecznościowe, Romowie, Polska, romanipen, cyfrowe rodzinowanie

\begin{abstract}
The article focuses on online social practices of the Polish Roma. The main context is provided by the COVID-19 epidemic accompanied by a period of lockdown from mid-March to the end of April 2020 and the necessity of social distancing. The research was conducted using online social interactions among the Polish Roma in Poland and their kin living abroad. As such, the internet functions as a source of information and opportunity to maintain social relations between the research participants. We point to the specifics of the Roma-generated online content before and after the pandemic. In this respect, we emphasize the way Roma culture and norms of common law "fit into" the Internet. It is on this ground that we introduce the concept of e-romanipen which describes the online shift in Roma culture. We interpret the intensification of online activity under the COVID-19 pandemic as an expression of collective agency and creativity aimed at cultural reproduction and maintenance of group cohesion at the time of threat and existential insecurity.
\end{abstract}

Key words: coronavirus (COVID-19), pandemic, migration, social media, Roma, Poland, romanipen, digital kinning 


\section{Wstęp}

W niniejszym artykule ${ }^{2}$ analizujemy rodzinne i towarzyskie praktyki polskich Romów w Polsce i za granicą (ze szczególnym uwzględnieniem Wielkiej Brytanii i Niemiec) w warunkach pandemii i towarzyszącemu jej stanowi zamknięcia (lockdown) oraz konieczności zachowania tak zwanego dystansu społecznego. Koncentrujemy się tu na okresie największych ograniczeń z przełomu marca i kwietnia 2020 roku $^{3}$. Zdajemy sobie sprawę, że opisywane zjawisko nie dotyczy wyłącznie Romów. Możemy wręcz zaryzykować twierdzenie, że na całym świecie niewiele jest grup, których praktyki te nie dotyczą. Wskazujemy jednak na specyfikę internetowego (zapośredniczonego) życia w odniesieniu do interesującej nas społeczności. Niezależnie od stanu pandemii, cyfrowe interakcje były już powszechne wśród Romów w Polsce i polskich Romów za granicą.

Reakcje na pandemię koronawirusa (COVID-19) sprawiły, że w warunkach globalnego zamknięcia życie społeczne przeniosło się do Internetu. Można to było zaobserwować między innymi podczas obchodzonej w kwietniu 2020 roku Wielkanocy, kiedy to media społecznościowe obrodziły zdjęciami i zrzutami ekranowymi „cyfrowego rodzinowania” (digital kinning) ${ }^{4}$ (Baldassar, Wilding 2020): rodzinnych spotkań, świątecznych obiadów, nagrań ze składania życzeń. Punktem wyjścia są dla

${ }^{2}$ Artykuł powstał w ramach projektu ,Transnarodowe życie polskich Romów - migracje, rodzina i granice etniczne w zmieniającej się Unii Europejskiej” finansowanego przez NCN w ramach grantu OPUS 16, nr UMO-2018/31/B/HS6/03006.

${ }^{3}$ Dostrzegamy fakt, że globalne zamknięcie nie było równomiernie rozłożone pomiędzy krajami (było to widoczne w przypadku Polski i Wielkiej Brytanii), różny był również jego wpływ na poszczególne grupy społeczne i zawodowe. Wyraźna część popularnych komunikatów internetowych (nie tylko w Polsce) koncentrowała się na lockdownie i ,narodowej kwarantannie”, pomijając sytuację osób, które w domach zostać nie mogły lub nie posiadały odpowiednich warunków do pracy i nauki w domu. W czasie pandemii koronawirusa opublikowano liczne opisy i interwencje odnośnie do sytuacji grup szczególnie narażonych na zakażenia lub pozbawionych możliwości komfortowego odbycia kwarantanny (pracownicy handlu i logistyki, migranci i uchodźcy, mniejszości etniczne i seksualne). Perspektywa lockdownu determinowana jest płcią, klasą, rasą czy przypisaniem do kultury mniejszościowej (zob. Sheller 2018, Glouftsios 2020). W omawianym przez nas okresie ograniczenia odnośnie do przemieszczania się, zgromadzeń i odwiedzin sprawiły, że jedni zmuszeni byli pozostać w domach, inni zaś nie mogli do nich wrócić lub w nich zostać (Glouftsios 2020).

${ }^{4} \mathrm{~W}$ polskojęzycznym Internecie popularny jest hasztag „rodzinowanie”. Odnosi się on do czasu spędzonego z rodziną, aktywności wspólnych, grillowania, spacerów, obiadów, imienin itp. 
Ignacy Jóźwiak, Elżbieta Mirga-Wójtowicz, Sonia Styrkacz, Monika Szewczyk

nas ustalenia Carol Silverman (1988), która jeszcze przed rozpowszechnieniem Internetu opisała używanie i adaptowanie przez Romów w USA nowoczesnych środków komunikacji indywidualnej i masowej (telewizja, radio, telefony). Badana przez nią grupa Romów na swój sposób wykorzystała technologię do zachowania swojej kultury i związanych z nią nisz ekonomicznych. Podobnie jak Silverman pokazujemy, w jaki sposób mniejszościowa kultura może być zachowana i przekształcona na warunkach danej grupy za pomocą nowoczesnych technologii i trendów. W sytuacji powszechnej internetyzacji oraz transnarodowego życia wykorzystanie nowych technologii może być pomocne, a nawet kluczowe w zachowaniu języka, tradycji i poczucia grupowej spójności Romów (Hajska 2019, Nagy 2018).

Internet i media społecznościowe to element dotychczas mało obecny w badaniach wśród polskich Romów (Fiałkowska, Garapich, Mirga-Wójtowicz 2018). Na polskim gruncie temat ten podjęła Joanna Talewicz-Kwiatkowska (2019), gros uwagi skupiając jednak na (skierowanych zarówno do Romów, jak i do szerszego grona odbiorców) międzynarodowych inicjatywach publicznych. Z kolei Marcin Szewczyk (2017), analizując anty-romskie komentarze polskich internautów, zwraca uwagę na cyfrowe wykluczenie polskich Romów, pomijając treści generowane przez Romów i dla Romów. Nasze obserwacje oraz codzienna aktywność przeczą tezie o braku cyfrowej aktywności tej grupy 5 .

Sama intensywna komunikacja internetowa tworząca transnarodowe pola społeczne nie jest niczym nowym dla osób migrujących. W sytuacji transnarodowego rozproszenia Internet umożliwia podtrzymanie więzi i zachowanie funkcji pełnionych w rodzinie (zob. Bielenin-Lenczowska 2015: 53-54; Patzer 2018). Stan zamknięcia na przełomie marca i kwietnia 2020 roku sprawił, że migrantki i migranci okazali się swego rodzaju „pionierami” w wykorzystywaniu technologii komunikacyjnych w celach „cyfrowego rodzinowania”. To, co okazało się nowe dla nie-migrującej

5 Pisząc o cyfrowym wykluczeniu, Szewczyk ma na myśli brak uczestnictwa w „ogólnonarodowym” dyskursie publicznym, a nie tworzenie treści przez Romów i dla Romów. Jednak nakreślony przez niego obraz sugeruje ogólną acyfrowość tej grupy: „Swoboda tworzenia treści w internecie nie stwarza szans dostępu Romów do uczestnictwa w dyskursie. Na drodze do tego stoi słaba znajomość języka polskiego, aliterackość ich kultury, skutkująca dość powszechną nieumiejętności formułowania wypowiedzi pisemnych i w wielu przypadkach wtórnym analfabetyzmem. (...) Nie bez znaczenia okazuje się także strona techniczna, wymagająca posiadania środków na zakup komputera i dostępu do internetu, a także umiejętność jego obsługi” (Szewczyk 2017: 227-228). 
globalnej większości, od lat stanowiło normę dla osób migrujących i ich rodzin (Baldassar i Krzyżowski 2020). Dotyczy to również polskich Romów w Wielkiej Brytanii i Niemczech. Nasze badanie, skupione wokół kreatywnego i sprawczego wykorzystywania cyfrowych komunikatorów i mediów społecznościowych, pokazuje, że Romowie, jak wszyscy mieszkańcy Polski, korzystają z nowoczesnych technologii przy jednoczesnym elastycznym zachowywaniu tradycji i obyczaju.

\section{Metodologia, etyka badań i charakterystyka terenu}

Podążając za apelem Fiałkowskiej, Garapicha i Mirgi-Wójtowicz (2018; 2020) o przełamanie w polskiej nauce akademickiej ciszy, której towarzyszy tendencja pisania o Romach bez Romów (zob. Kapralski 2016) oraz pomijania wielu istotnych wymiarów życia tej grupy, sytuujemy nasze badania w nurcie dekolonizacji wiedzy oraz badań partycypacyjnych w odniesieniu do Romów i osób współpracujących (Silverman 2018; Mirga-Kruszelnicka 2018; Gay y Blasco, De La Cruz Hernandez 2012). Nasze dyskusje w ramach romsko-gadziowskiego ${ }^{6}$ zespołu badawczego wychodzą naprzeciw potrzebie wypracowania wspólnej, intersubiektywnej perspektywy w procesie pozyskiwania i interpretacji danych.

$\mathrm{Z}$ uwagi na centralną rolę Internetu niniejsze studium wpisuje się również w etnografię cyfrową (Caliandro 2017; Pink i in. 2016; Zdrodowska 2014). Oznacza to prowadzenie badań w Internecie i za jego pośrednictwem, ale nie badanie samego Internetu i internetowych społeczności. Internet traktujemy tu jako źródło informacji i sposób zapośredniczonego kontaktu z uczestnikami i uczestniczkami badania. Stanowi on dla nas nie tylko technikę, ale również część szerszego procesu zbierania danych i obecności w terenie. Internetowe zapośredniczenie zostało zintensyfikowane z powodu pandemii i lockdownu, za sprawą których musieliśmy zmodyfikować nasze plany badawcze. To, co z początku wydawało się ograniczeniem, otworzyło jednak nowy obszar i metody badań.

Część osób, których aktywność jest przedmiotem naszego studium, jest

\footnotetext{
${ }^{6} \mathrm{~W}$ języku romskim termin Gadzio określa nie-Roma, jest terminem odgradzającym Romów od społeczeństwa większościowego. To kluczowa kategoria określająca granicę etniczną, która w literaturze polskiej oddawana jest jako termin typu emic, pisany kursywą. W literaturze anglojęzycznej funkcjonuje jako akceptowana forma nazwy własnej - Gadjo. W niniejszym artykule używamy jednak terminów „Gadzio”, „Gadzie” i „gadziowski" bez kursywy.
} 
Ignacy Jóźwiak, Elżbieta Mirga-Wójtowicz, Sonia Styrkacz, Monika Szewczyk

nam znana w rzeczywistości offline, niektóre z nich poznaliśmy w trakcie wcześniejszych badań. Obserwacja online umożliwia nam podążanie za osobami z badanej społeczności i obserwowanie ich praktyk w życiu codziennym w tym specyficznym czasie. Część z nas na co dzień aktywnie korzysta z romskich mediów społecznościowych i grup dyskusyjnych, komentując i udostępniając treści powiązane $\mathrm{z}$ tematyką badań. W celach badawczych korzystamy z własnych kont zawierających prawdziwe dane osobowe. Cyfrowa obserwacja uczestnicząca miała więc dla nas elementy autoetnografii.

Media społecznościowe stanowią dla nas przestrzeń interakcji nieodłączną od innych form aktywności i relacji społecznych (Pink i in. 2016). Prowadząc badania za pośrednictwem Internetu, zwracamy uwagę na tworzenie i podtrzymywanie praktyk zapewniających ciągłość grupy, która nie jest definiowana przez Internet i media społecznościowe. Etnografia mediów społecznościowych skupia się więc na praktykach wokół określonego zagadnienia (Caliandro 2017), którym jest tu pandemia oraz czas świąteczny w jej warunkach. Nasze badania prowadzone za pośrednictwem Internetu są więc ściśle zintegrowane z rzeczywistością offline, która stanowiła punkt wyjścia. Rzeczywistość online, jak wynika z naszych badań, płynnie przechodzi w offline, jednak w czasie pandemii staje się dominującą platformą kontaktu i komunikacji.

Analizując treści online, przekraczamy ramy czasowe i przestrzenne. Przyjęta przed pandemią wielostanowiskowość naszych badań (prowadzonych w różnych lokalizacjach z uwzględnieniem ich wzajemnych powiązań) wraz z intensyfikacją internetowych obserwacji nabrała również cech badań poza-terenowych (prowadzonych w przestrzeni publicznej nieposiadającej określonych granic) (zob. Airoldi 2018). Podstawowy materiał badawczy stanowią dla nas treści wygenerowane przez użytkowników portali społecznościowych.

Większość analizowanych przez nas treści jest ogólnodostępna. Komunikaty aktywistów oraz filmiki z „,nominacjami” i „czelendżami”7 są kierowane do szerokiego grona odbiorców. Analizujemy również treści zawarte na forum, które jest zamkniętą grupą na Facebooku. Do grupy należy kilkanaście tysięcy osób, więc nie obowiązuje na niej restrykcyjna selekcja. Kierując się zasadą poufności oraz troski o dobro uczestników i uczestniczek badania (Boellstorff i in. 2012), nie identyfikujemy

\footnotetext{
${ }^{7}$ Stosujemy tutaj używaną w mediach społecznościowych spolszczoną formę słowa challange - wyzwania rzuconego w ramach internetowych gier i zabaw.
} 
poszczególnych osób, anonimizujemy również osoby publicznie rozpoznawalne, nie ujawniamy nazw grup i portali. Nie publikujemy również fotografii ani zrzutów ekranowych oraz powstrzymujemy się od oceny opisywanych zachowań ${ }^{8}$. Naszym celem nie jest przekazanie ,wyniesionych" z Internetu informacji o życiu i problemach społeczności, wśród której prowadzimy badania, lecz ukazanie roli, jaką Internet pełni w transnarodowych romskich rodzinach. Obserwując internetową aktywność, staramy się również uchwycić proces postępującej cyfryzacji kultury w okresie nacechowanym sprzecznością pomiędzy potrzebą intensywnych spotkań (Międzynarodowy Dzień Romów, Wielkanoc) a odosobnieniem (pandemia i lockdown). Bardziej niż jednostkowe treści interesuje nas całościowa forma, jaką przybiera kultura i życie społeczne w dobie pandemii i przymusowego zamknięcia.

Obserwację prowadziliśmy od początku marca do połowy maja 2020 roku, co pozwoliło na uwzględnienie poszczególnych stadiów pandemii od jej początku poprzez czas lockdownu aż po jej oczekiwany - niedoczekany - koniec latem 2020, kiedy stopniowo znoszono ograniczenia dotyczące spotkań i przemieszczania się. W badaniu wykorzystaliśmy 28 różnego rodzaju materiałów: nagrań z komunikatami romskich aktywistów i celebrytów, postów, statusów, udostępnianych artykułów internetowych, komunikatów osób i działaczy organizacji przedstawiających się jako reprezentanci społeczności Romów w Polsce i polskich Romów za granicą. Materiały te prezentowane były na różnych forach i grupach, fanpage'ach organizacji i osób mających status publiczny. Należy podkreślić, że prezentowany materiał jest jedynie niewielkim wycinkiem spośród dostępnych w Internecie treści. Materiał możemy podzielić na trzy grupy: 1. Odezwy, komunikaty, apele liderów (łącznie 9 krótkich filmów udostępnionych przez trzy osoby zaliczone przez nas do romskich liderów); 2. Krótkie filmy i zrzuty ekranowe (print screeny) z internetowych wyzwań (,czelendży”); 3. Audiowizualne materiały dotyczące koronawirusa.

${ }^{8}$ Tego rodzaju zapośredniczone badanie rodzi również pytania natury etycznej. Dylematy są na tym polu podobne do ,standardowych” wyzwań w tym zakresie (Boellstorff $\mathrm{i}$ in. 2012, Fiałkowska 2018). Dodatkowym wyzwaniem jest między innymi potencjalna jednostronność przekazu i odbioru (Fiałkowska 2018; Hajska 2019). 
Ignacy Jóźwiak, Elżbieta Mirga-Wójtowicz, Sonia Styrkacz, Monika Szewczyk

Romski Internet i e-romanipen, czyli nowe technologie na straży tradycji

„Przedinternetowe” badania Carol Silverman (1988) pokazują, w jaki sposób nowoczesne technologie komunikacji i pop-kultura mogą być wykorzystywane dla utrzymania romskości - w tym przypadku wśród Kalderaszy i Lowarów w Stanach Zjednoczonych. Jednym z wniosków Silverman jest to, że wypracowane w łonie kultury dominującej innowacje nie muszą być zagrożeniem dla tożsamości i kultury grup mniejszościowych. Zmiany wynikają tu ze świadomych działań adaptacyjnych i strategii na rzecz przetrwania kultury w nie-romskim otoczeniu, zaś innowacje w jednym obszarze mogą przyczynić się do wzmocnienia konserwatyzmu w innych sferach (Silverman 1988: 268). Taką innowacją jest Internet, który nabiera dodatkowego znaczenia w kontekście transnarodowym, stając się integralną częścią życia codziennego. Sprzyja temu popularność smartfonów i praktycznie powszechna dostępność sieci, nawet w mniej zamożnych rodzinach.

Istotne $\mathrm{w}$ tym kontekście są ustalenia $\mathrm{z}$ badań o roli Internetu wśród węgierskich i słowackich Romów w Wielkiej Brytanii (Nagy 2018; Hajska 2019). W warunkach internetyzacji media społecznościowe i grupy dyskusyjne stały się elementem podtrzymywania kontaktu, wymiany treści, a tym samym budowania tożsamości i grupowej solidarności na poziomach lokalnym i transnarodowym (czy translokalnym, na temat rozróżnienia zob. White 2011). Media społecznościowe umożliwiają również kontrolę oraz wyrażanie troski ze strony rodziny i społeczności, a w konsekwencji zachowanie (nawet jeżeli w zmienionej formie) kultury i tożsamości grupy mniejszościowej (Nagy 2018). Marketa Hajska (2019) dostrzega rolę Internetu i mediów społecznościowych (zwłaszcza Facebooka) nie tylko w zachowaniu kultury i wewnątrzgrupowych więzi, ale także w autokreacji i budowaniu wizerunku osób mieszkających za granicą, a wywodzących się ze słowackiej społeczności Vlaska Roma9 . Odbywało się to za pośrednictwem treści wychodzących naprzeciw domniemanym oczekiwaniom społeczności, przede wszystkim w postaci eksponowania atrybutów tradycyjnie przypisywanych tej grupie oraz ogólnego wizerun-

${ }^{9}$ Vlaska Roma to grupa zamieszkująca Słowację, Węgry i ukraińskie Zakarpacie, stanowiąca mniejszość wśród Romów w tych krajach. Tradycyjnie byli społecznością wędrowną, zajmowali się hodowlą i handlem końmi. Pod względem języka i stylu życia bliscy są grupie Lowarów. 
ku migrantów jako ludzi sukcesu. Jej analiza skupia się na materiale wizualnym, takim jak fotografie i selfies.

Internet stanowi miejsce, w którym silnie i w specyficzny sposób uwidaczniają się związane $\mathrm{z}$ wyzwaniami współczesności zmiany zachodzące w życiu, także życiu online, Romów. Jest to przestrzeń, w której wyraźnie przeplatają się kultury międzygrupowe różnych grup romskich z Polski (najbardziej liczne to Polska Roma, Bergitka Roma, Lowarzy, Kelderasze), języki oraz międzypokoleniowe różnice w stylach życia (w tym obecności w Internecie). W sieci obecne są osoby z różnych pokoleń. Młodzież transmituje do sieci elementy romskiej obyczajowości, jednocześnie redefiniując je i kontestując. Osoby ze starszego pokolenia obserwują ten trend, a niektóre $\mathrm{z}$ nich starają się go zatrzymać lub przynajmniej „ocenzurować” pewne jego aspekty.

Niezależnie od obyczajowych kontrowersji Internet stanowi przestrzeń umożliwiającą konsolidację romskich wspólnot (zastosowanie liczby mnogiej wynika $z$ chęci podkreślenia ich zróżnicowania) i stworzenie przystępnej, acz niewidocznej dla Gadziów, bezpiecznej przestrzeni dla języka i codziennej kultury. Dla rozbudowanych, sięgających Niemiec, Szwecji i Wielkiej Brytanii rodzin romskich Internet okazał się przestrzenią, dzięki której „transnarodowe rodzinowanie” stało się nie tylko znacznie łatwiejsze, ale również powszechnie dostępne dzięki funkcjonalnie wykorzystywanym narzędziom do bieżącej komunikacji i utrzymywania kontaktu z krewnymi.

Istotnym pojęciem stosowanym do określenia „romskości” jest prawo zwyczajowe romanipen (Mirga i Mróz 1994: 127; Koper 2018: 170), definiujące tożsamość grupy i wytyczające jej granice (Bartosz 2004: 170171). Podkreślić należy, że romanipen jako swego rodzaju życiowa filozofia ma płynny charakter i nie jest jednoznacznie skodyfikowanym systemem norm i wartości, zaś jego rola i treść są różne dla różnych grup polskich Romów. $Z$ tego też względu jest on różnie interpretowany w badaniach romologicznych (zob. Koper 2018; Koper 2020) ${ }^{10}$. W warstwie wizualnej i performatywnej demonstrowany jest on także za pomocą ubioru, biżuterii, wyposażenia i aranżacji wnętrz, sposobu nakrywania i prezentacji stołów biesiadnych, dobierania kolorów oraz składników do potraw. Najbardziej widoczne jest to w przypadku kobiet, które są postrzegane jako

${ }^{10}$ Rola romanipen, jego różne interpretacje i przemiany to zagadnienie zasługujące na osobne opracowanie. Przegląd istniejących definicji znajdujemy u Tomasza Kopra (2020). 
Ignacy Jóźwiak, Elżbieta Mirga-Wójtowicz, Sonia Styrkacz, Monika Szewczyk

depozytariuszki i strażniczki tradycji (zob. Anthias i Yuval-Davis 2005). To na nich w dużym stopniu ciąży obowiązek dbania o wizerunek rodziny, aby zasłużyć na szacunek, jakim ich rodzina będzie darzona wśród Romów. Kontrola społeczna dotycząca zgodności z romanipen bardzo często polega na obserwacji i ocenie zachowań, w tym sposobu komunikowania się z Romami i Gadziami.

Migracja i odległość powodują, że sprawy te nabierają szczególnej wagi, ponieważ utrudnione staje się sprawowanie kontroli społecznej i wywieranie wpływu na młodsze pokolenia. Tutaj z pomocą może przyjść Internet. Jednak niejednoznaczność norm składających się na romanipen przejawia się również w podejściu do Internetu oraz tego, kto i w jakim stopniu może z niego korzystać. Jest to szczególnie problematyczne w przypadku osób starszych i kobiet. Spotkaliśmy się z opiniami, że z mediów społecznościowych nie powinna korzystać paciwali rom$n i$ (szanowana kobieta o wysokiej pozycji społecznej) lub przynajmniej powinna korzystać w sposób nie rzucający się w oczy ${ }^{11}$. Sprawia to, że $\mathrm{w}$ romskich grupach w mediach społecznościowych pojawia się wiele kont o „fejkowej” nazwie użytkownika oraz z nierzeczywistym zdjęciem profilowym. Osoba, która podaje w portalu społecznościowym pełne dane oraz zdjęcie, musi być świadoma, że podlega ocenie rodziny i krewnych. Kobiety silniej odczuwają tę wewnątrzgrupową ocenę niż mężczyźni, dlatego z naszych obserwacji wynika, że praktyka takich kont częstsza jest u kobiet niż u mężczyzn.

Częste jest również posiadanie wspólnych kont z małżonkiem/małżonką, partnerem/partnerką lub dziećmi. Chronią one przed potencjalnym pomówieniem dotyczącym sposobu korzystania z Internetu. Starsze osoby często obawiają się mediów społecznościowych i nie rozumieją ich, co nie zmienia faktu, że niektóre z nich są świadome płynących z nich korzyści i zagrożeń. Kolektywizm przyjęty w zachowaniach dotyczących poszanowania ogólnie przyjętych zasad romanipen oznacza silniejszą kontrolę społeczną w tym zakresie. Dla młodszych pokoleń poziom wykorzysta-

${ }^{11}$ Termin ten związany jest ze zjawiskiem (zasadą prawa zwyczajowego) paćiw ( $p a-$ ciw w dialekcie języka romskiego grupy Bergitka Roma albo patyw w dialekcie grupy Polska Roma). Oznacza on demonstracyjne wyrażanie i okazywanie szacunku rodzinie i gościom. Patyw/paćiw może oznaczać przyjęcie wydane na czyjąś cześć, w czasie którego przestrzega się symbolicznej czystości przygotowania i spożywania potraw i honoruje gości ze względu na płeć i wiek. Może dotyczyć również określenia cechy osoby, Paćiwali/Patywali Romni i Paćiwało/Patywało Rom to osoby godne szacunku, ogólnie szanowane w społeczności. 
nia mediów elektronicznych w życiu codziennym stał się wyznacznikiem przynależności, stylem życia i ma istotny wpływ na wiele jego aspektów, w tym na relacje międzyludzkie (także na życie emocjonalne i seksualne), wyznawany system wartości, aktywność zawodową i zainteresowania. Obawa przed ostracyzmem powoduje, że wiele osób korzysta z „fejkowych" kont.

Samo tworzenie treści online w języku romskim jest elementem konstruowania granicy etnicznej (zob. Barth 2004). Potencjalny obserwator, który nie rozumie języka romskiego i nie jest Romem, odczytuje taki obraz w sposób odmienny niż osoba, do której jest skierowany komunikat. Czasem przekaz jest celowo zniekształcony, aby uniemożliwić jego pełne zrozumienie przez Gadziów. Internetowe rozrywki nie służą zatem jedynie spędzaniu wolnego czasu, zawierają również przekaz dotyczący postępowania konkretnych osób oraz jego zgodności z obyczajem i oczekiwaniami grupy. W tym sensie Internet stał się dla Romów potężnym narzędziem podtrzymującym tradycje przy jednoczesnym zacieśnianiu relacji międzyludzkich i społecznych, stając się także potencjalnym narzędziem kontroli. Symboliczne granice oddzielające świat romski od świata gadziowskiego wytwarzane i podtrzymywane są za pośrednictwem praktyk życia codziennego, w tym aktywności online. Takie działania pozwalają zachować poczucie wspólnoty i kulturowej odrębności pomimo zmieniających się uwarunkowań oraz intensywnego kontaktu i wymiany kulturowej ze światem Gadziów (por. Okely 1983: 77; Okely 2018: 62).

Opisane wyżej zjawisko przeniesienia kultury romskiej do Internetu i jej adaptacji do cyberprzestrzeni określamy sformułowanym przez Monikę Szewczyk pojęciem e-romanipen. Wiąże się ono z kontekstowym uwikłaniem werbalnych (język) i niewerbalnych (warstwa wizualna) znaczeń kultury romskiej w konstrukcji komunikatu internetowego, obejmującego zarówno nadawcę, jak i odbiorcę przekazu.

\section{Transnarodowość i Internet w wydaniu polskich Romów w kraju i za granicą}

W naszym badaniu skoncentrowaliśmy się na interaktywnym aspekcie mediów społecznościowych, za jakie uznajemy fora dyskusyjne oraz internetowe (lub rozpowszechniane za pomocą Internetu) rozrywki. Kontekst autokreacji i działań konsolidujących grupę sprawia, że dostrzegamy 
Ignacy Jóźwiak, Elżbieta Mirga-Wójtowicz, Sonia Styrkacz, Monika Szewczyk

kwestię tego, co wyeksponowane i tego, co przemilczane, potencjalnej autocenzury oraz ewentualnych zagrożeń mogących płynąć z nieograniczonego dostępu do informacji.

Niezależnie od kontekstu migracyjnego, wokół korzystania przez polskich Romów z Internetu narosło wiele nieporozumień, kontrowersji oraz niedomówień i plotek. Wynikają one z dość egalitarnego dostępu do informacji, możliwości jej niekontrolowanego udostępniania oraz anonimowości (mogącej iść w parze z bezkarnością) użytkowników Internetu. Ze względu na potencjalne zagrożenia dla tradycyjnej obyczajowości temat regulacji zachowań w cyberprzestrzeni powraca w dyskusjach między Romami co najmniej od pierwszej dekady XXI wieku. Wśród starszyzny pojawiały się plany objęcia korzystania z sieci zakazami prawa zwyczajowego. Z naszych informacji wynika, że po licznych dyskusjach w środowisku grupy Polska Roma w 2019 roku używanie Internetu w celach innych niż zarobkowe zostało objęte restrykcjami wydanymi przez Śero Roma ${ }^{12}$. Zakaz ten, ogłoszony za pomocą internetowego medium (YouTube), miał zdaniem starszyzny uchronić przede wszystkim romską młodzież oraz kobiety od zachowań uchodzących za niemoralne, niebezpieczne lub stawiające w złym świetle ich rodziny i społeczność romską (Talewicz-Kwiatkowska 2019: 239). Warto tutaj zaznaczyć, że nakazy i zakazy Śero Roma uznawane są za wiążące tylko przez część Romów w Polsce. Autorytet ten uznaje przede wszystkim grupa Polska Roma, podczas gdy Romowie z grupy Bergitka Roma szanują go jako członka starszyzny, ale tradycyjnie nie uznają go za najwyższy autorytet prawa zwyczajowego.

Nasze badania oraz codzienna internetowa aktywność niektórych z nas w sposób jednoznaczny świadczą o tym, że internetowa komunikacja, z wykorzystaniem komunikatorów takich jak Messenger, Skype i Whatsapp, jest niezwykle ważna dla romskich rodzin. Do języka romskiego na stałe weszły przystosowane językowo nazwy komunikatorów, jak mesendżeris, fejsbukos, skejpos, wotsapos. Należy przy tym zwrócić uwagę, że użytkownikami komunikatorów są Romowie pochodzący z różnych grup romskich i posługujący się różnymi dialektami języka romskiego. $\mathrm{Z}$ tego też względu w zależności od dialektu grupy słowa otrzymują od-

12 Śero Rom (dosłownie Głowa Romów, po polsku nazywany również Romskim Królem) to autorytet uznawany przez grupę Polska Roma za zwierzchnika w zakresie prawa zwyczajowego. Przez Romów z innych grup jest szanowany, za czym nie idzie jednak uznanie jego ,zwierzchnictwa”. 
powiednią formę gramatyczną, i tak np. angielskie słowo Facebook może przybrać formę fejsbuko, fejsbukos, fejsbukura.

Media społecznościowe pozwalają również obserwować (oraz nadzorować) aktywność poszczególnych członków czy konkretnych rodzin i klanów w zakresie stosowania się do zakazów i nakazów oraz tradycyjnego systemu-kodeksu wartości utożsamianych z romanipen, ale też mageripen (zwyczajowy system nakazów i zakazów). Natomiast dla młodego pokolenia media społecznościowe stanowią narzędzie ułatwiające zawieranie znajomości, randkowanie i wybór partnerów. Pociąga to za sobą uniwersalny problem niemoralnych czy niebezpiecznych, według tradycji, zachowań. Współcześnie rolę dawnych form pośrednictwa w poszukiwaniu partnera życiowego pełnią portale randkowe, co wywołuje zrozumiałe obawy starszego pokolenia, które często utożsamia z nimi media społecznościowe. Zdaniem niektórych już samo posiadanie konta na Facebooku może być synonimem poszukiwania męża lub żony. Kojarzenie małżeństw tradycyjnie należało do rodziców młodej pary. Było jednym z wyznaczników skutecznej reprodukcji kulturowej, ale też posłuszeństwa młodych. W dobie cyfryzacji tradycyjne swatanie zyskuje nowe elementy w postaci internetowych transmisji uroczystości i spotkań. Zdarza się, że młodsze pokolenie przejmuje inicjatywę online bez udziału osób ze starszego pokolenia i tak inicjują znajomość, jednak później proces faktycznych zaślubin przebiega tradycyjnie, a internetowe transmisje z tych uroczystości i imprez stają się bardzo popularne. Pandemia i okres izolacji pozwoliły nam jednak zaobserwować nowy element w strategiach kojarzenia przyszłych małżonków. Wobec niemożliwości zorganizowania przyjęcia czy imprezy zaręczynowej, publikowane są w Internecie w jak najszerszym gronie rodzinnym zdjęcia przyszłej pary młodej. Zabieg taki ma na celu poinformowanie rodziny, przyjaciół i znajomych o fakcie zaręczyn, przekazanie informacji, że związek uzyskał zgodę rodziców. W społecznościach o silnych i bardzo rozgałęzionych sieciach rodzinnych Internet stanowi zatem funkcjonalne narzędzie kulturowej reprodukcji, kontroli społecznej i wewnętrznej integracji grupowej, ale też wyzwanie dotyczące skutecznej socjalizacji w zgodzie z tymi wartościami. 
Ignacy Jóźwiak, Elżbieta Mirga-Wójtowicz, Sonia Styrkacz, Monika Szewczyk

\section{Internet jako romskie kroniki zarazy}

Nasze obserwacje pokazują różnorodne sposoby, na jakie Romowie radzą sobie w czasie pandemii. Po ogłoszeniu stanu epidemii zaobserwowaliśmy wzmożenie dyskusji dotyczących strategii migracyjnych (dylemat decyzji o powrocie do Polski lub pozostaniu w kraju pobytu), toczonych na forach internetowych, jak również w bezpośrednich kontaktach między członkami rodzin rozsianych po różnych krajach. Głównym źródłem wiedzy o epidemii była polska telewizja i informacje od członków rodzin mieszkających w Polsce (przekazywane przez komunikatory i media społecznościowe). W społecznościach internetowych wymieniano opinie i spekulacje. Wyraźnie zapanował niepokój wobec możliwości zamknięcia granic, co oznaczało perspektywę utrudnionego powrotu do miejsc pochodzenia. W związku z tym na jednej z romskich grup facebookowych pojawiły się posty proponujące wspólny przejazd z Wielkiej Brytanii do Polski w kolumnie kilku samochodów. Jednemu z tych ogłoszeń towarzyszyło ostrzeżenie, że „tutaj [w Wielkiej Brytanii] umrze połowa ludzi”. Z innej wypowiedzi dowiadujemy się, że Anglię opuszcza kierująca się do Polski kolumna kilkudziesięciu samochodów. Niezależnie od swojej rzeczywistej skali te reakcje i obawy wobec pozostania w Wielkiej Brytanii wpisują się w często wyrażany przez migrantów z Polski - nie tylko Romów - brak zaufania i krytyczny stosunek do brytyjskiej służby zdrowia (zob. Osipovič 2013). W połączeniu z barierą językową (dobra znajomość języka angielskiego nie jest wśród migrantów regułą) ten brak zaufania i niepewność u niektórych wzmógł tęsknotę za domem i rodziną w Polsce.

W kontekście pandemii warto podkreślić, że Internet stanowi główną platformę komunikacji dla romskich przywódców i celebrytów, którzy mają swoich odbiorców także wśród polskich Romów mieszkających za granicą. Na potrzeby niniejszego opracowania zidentyfikowaliśmy 6 osób pełniących rolę liderów (w tym religijnych), autorytetów, działaczy organizacji pozarządowych, ludzi z branży muzycznej, sportowców. Pomimo publicznego charakteru działalności tych osób, pisząc o nich stosujemy nadane przez nas pseudonimy. Ten zabieg pozwala nam skoncentrować się na opisywanych zjawiskach, a nie na konkretnych osobach, oraz zapewnić anonimowość osób odwiedzających te publicznie dostępne profile i zostawiających tam swoje komentarze.

Jeden z liderów, nazywany przez nas Celebrytą, który jest szczególnie aktywny w mediach społecznościowych, kreuje swój wizerunek nie tylko 
romskiego autorytetu, ale także pośrednika pomiędzy Romami a resztą polskiego społeczeństwa. Jego sceniczna charyzma połączona z doradczą funkcją w obszarze polityk publicznych sprawia, że jest on powszechnie rozpoznawany wśród polskich Romów w kraju i zagranicą (w Wielkiej Brytanii, Szwecji, Niemczech). Kierując swoją działalność zarówno do Romów, jak i Gadziów, występuje w podwójnej roli: szacownego członka społeczności romskiej oraz dobrego obywatela i religijnego Polaka. Po wybuchu pandemii on i inni romscy liderzy przyłączyli się do kampanii \#zostańwdomu, zachęcając społeczności, które reprezentują i na rzecz których pracują, do stosowania się do zaleceń władz i ekspertów medycznych. Wszyscy solidarnie zrezygnowali ze spotkań i wszelkiej pozainternetowej aktywności. Celebryta zorganizował zbiórkę pieniędzy na wsparcie instytucji medycznych, która miała także cel wizerunkowy, mianowicie przełamania stereotypu Roma - osoby zależnej od pomocy społecznej, kojarzonego z postawą roszczeniową i nieangażującego się w pracę na rzecz innych. Z kolei lider, którego nazywamy Muzykiem, wystawił na aukcję swoje kostiumy sceniczne oraz instrumenty w ramach akcji mającej wspomóc personel medyczny w pobliskim szpitalu. Celebryta tuż przed Wielkanocą zainicjował popularne w mediach społecznościowych ,czelendże” i związane z nimi ,nominacje”, w których wyznaczone osoby miały za zadanie śpiewać piosenki i grać muzykę, aby umilić wszystkim czas podczas kwarantanny. W rywalizację szybko włączyli się zarówno profesjonalni muzycy, jak i amatorzy.

Kilka organizacji romskich prowadziło w Internecie zbiórki środków na zakup maseczek ochronnych i środków higienicznych na portalach zbiórkowych, równocześnie ukazało się kilka artykułów prasowych opisujących i zwracających uwagę na sytuację Romów w Europie i w Polsce. Jedna $\mathrm{z}$ romskich organizacji wraz ze stowarzyszeniami pracującymi na rzecz społeczności migranckich w Polsce, w tym Romów rumuńskich, opracowała materiały informacyjne dotyczące koronawirusa w języku polskim oraz $\mathrm{w}$ dwóch dialektach języka romskiego. Również osoby niezwiązane bezpośrednio z aktywizmem na rzecz Romów, ale popularne w środowisku romskim, chętnie brały udział w koncertach online i innych inicjatywach zarówno charytatywnych (wspierających służbę zdrowia ${ }^{13}$ ), jak i po prostu umilających czas w tym trudnym okresie.

13 Romscy artyści wzięli udział między innymi w ogólnopolskiej inicjatywie \#hot16challange2. 
Ignacy Jóźwiak, Elżbieta Mirga-Wójtowicz, Sonia Styrkacz, Monika Szewczyk

Aktywni uczestnicy otwartych i zamkniętych grup na portalach społecznościowych byli dobrze poinformowani o aktualnej sytuacji politycznej i społecznej w Polsce. Na bieżąco wstawiano posty informacyjne. Reakcje użytkowników i użytkowniczek mediów społecznościowych na pandemię koncentrowały się wokół czterech tematów: religii, bezpośrednich relacji w czasie pandemii, humoru oraz polityki i teorii spiskowych. Posty związane z religią dotyczyły modlitw, charakterystyczne było wstawianie zdjęć świętych osobistości. Pojawiły się również transmisje online różnych zgromadzeń religijnych, prowadzonych w języku romskim, w których użytkownicy łączyli się z prowadzącymi aby wspólnie pomodlić się lub porozmawiać. W bezpośrednich relacjach z przebiegu pandemii wyróżniały się posty z szokującymi zdjęciami i krótkimi filmami. Były to np. relacje z pobytu w szpitalach i nagrania, których bohaterami były osoby zmarłe na COVID-19. Posty dotyczące polityki nawiązywały do wypowiedzi polskich i zagranicznych polityków i filmów na YouTube. Poruszały również temat wprowadzanych w poszczególnych krajach obostrzeń, a także omawiały teorie spiskowe. Wszystko to interpretujemy jako próby oswojenia lęku przed nieznaną i potencjalnie niebezpieczną chorobą oraz znalezienia pocieszenia i poszukiwanie przyczyn zaistniałej sytuacji.

Wkrótce, poza wspomnianymi wyżej muzycznymi wyzwaniami, wśród innych użytkowników pojawiły się wyzwania takie jak pieczenie ciast, lepienie pierogów czy transnarodowe wznoszenie toastów za zdrowie krewnych oraz odganianie koronawirusa i złorzeczenie mu. Z naszych obserwacji wynika, że wraz z postępem epidemii transmisje radosnych biesiad i innych zbiorowych imprez stopniowo zastąpiły gry i rywalizacje, nominacje i „,czelendże”, a w komunikacji szybko zagościły takie słowa jak nomininet, nomininaw, czelendżos i czelendżo. W jednym z filmików widzimy mężczyznę pozdrawiającego swoją rodzinę w Polsce, Wielkiej Brytanii i Niemczech, a następnie nominującego kolejne osoby do wzniesienia toastu za rychły koniec koronawirusos. Toasty i spożywanie alkoholu podejmowane były głównie przez mężczyzn, ale kobiety (nawet jeżeli mniej widoczne) również były w nich obecne, filmując, przypominając, kogo należy pozdrowić, i pomagając $\mathrm{w}$ doborze słownictwa (odpowiedniki angielskich i polskich słów w języku romskim) związanego z mediami społecznościowymi. Inne nagranie pokazuje odświętnie ubranego mężczyznę, który podjął się „czelendżu”. Bohater krótkiego filmu siedzi przy elegancko nakrytym stole, na którym widoczny jest markowy alkohol, a $\mathrm{w}$ tle porcelanowe figurki barokowych postaci. Wizualny przekaz tego 
krótkiego filmu wzmacnia grająca w tle muzyka z filmu Ojciec Chrzestny Francisa Forda Coppoli. Mężczyzna pozdrawia wszystkich oglądających, spokojnym, ale stanowczym głosem dziękuje za nominację i wznosi toast wielkim kielichem za pomyślność wszystkich ludzi, za opiekę Boga, życzy wszystkim spokojnych i zdrowych świąt i dużo zdrowia. Całość przemówienia odbywa się w języku romskim.

Innym rodzajem wyzwań jest przygotowywanie pierogów oraz potraw okołoświątecznych. Tu szczególnie popularne „,czelendże” dotyczą wielkich zawijanych placków drożdżowych z bakaliami i owocami i pierogów ruskich oraz pierogów z kaszanką. Towarzyszą temu życzenia zdrowia i pomyślności oraz ochrony przed koronawirusos. Wznoszone są również toasty wysokoprocentowym alkoholem; wyzwań związanych z toastami i spożywaniem alkoholu podejmują się wyłącznie mężczyźni. Większość wypowiedzi pada w języku romskim, choć zdarzają się też pojedyncze wyrazy w języku polskim. Pierogi przygotowują mężczyźni instruowani zza kamery telefonu przez swoje partnerki i żony, natomiast słodkie wypieki przygotowują zarówno mężczyźni, jak i kobiety. Co ciekawe, wyzwania tego rodzaju kierowane i podejmowane są raczej przez osoby w średnim wieku lub starsze. Osoby młode odpowiedzialne są za filmowanie i udostępnianie. Innym podejmowanym w ,czelendżach” wyzwaniem było wykonywanie ćwiczeń fizycznych. Nominowane osoby musiały wykonać konkretną liczbę ćwiczeń (np. pompek) w odpowiednim czasie. Najczęściej nominowani byli młodzi mężczyźni.

\section{Cyfrowe świętowanie w okresie lockdownu}

W celu wprowadzenia w zagadnienie świętowania w interesującym nas okresie, poniżej przedstawiamy przebieg niedzieli wielkanocnej, która była udziałem jednej z nas. Oto jej relacja:

Spotkanie rodzinne odbyło się w formie wideokonferencji, w której wzięła udział moja rodzina mieszkająca w Anglii i w dwóch miastach w Polsce. Wśród uczestników i uczestniczek były też osoby na co dzień mieszkające w bezpośrednim sąsiedztwie. Atmosfera była świąteczna i rodzinna. Były żarty, toasty, oglądanie i wysyłanie starych zdjęć. Niektórzy śpiewali i tańczyli, jeden z kuzynów grał na akordeonie. Drugi kuzyn był jednocześnie obecny na trzech różnych połączeniach za pomocą dwóch telefonów i jednego komputera. Po pewnym czasie 
Ignacy Jóźwiak, Elżbieta Mirga-Wójtowicz, Sonia Styrkacz, Monika Szewczyk

starsze pokolenie opuściło rozmowę wideo, pozostawiając młodemu pokoleniu więcej swobody. Jedna z ciotek co jakiś czas wpadała, żeby dyskretnie sprawdzić, czy młodzi odpowiednio się zachowują. Pierwszy raz w życiu doświadczyłam tego, że Romowie nie odwiedzali się podczas Świąt, świadomie (z obawy przed zarażeniem siebie lub innych) podejmując decyzję o izolacji. Z doświadczenia wiem, że Romowie bardzo się boją chorób, szpitali. Ten strach uziemił ich w domach. Możliwość prowadzenia rozmowy w czasie rzeczywistym z opcją wideo dała namiastkę bycia razem i świadomość, że wszyscy mają się dobrze. Niemniej jednak to w żaden sposób nie zastąpi tradycyjnych spotkań świątecznych i innych uroczystości.

Filmowanie, transmitowanie na żywo i udostępnianie w mediach społecznościowych różnego rodzaju życiowych wydarzeń (chrzciny, urodziny, śluby, pogrzeby) cyklicznych świąt (Wszystkich Świętych, Boże Narodzenie, Wielkanoc) już wcześniej było popularne wśród romskich rodzin, szczególnie tych terytorialnie rozproszonych. Istotnym aspektem tego typu zgromadzeń jest jedzenie i wspólne ucztowanie w gronie bliskich. Jest to ważna część romskiej kultury, wzmacniająca więzi i poczucie grupowej solidarności oraz przypominająca o grupowych hierarchiach. Popularne transmitowanie imprez przy zastawionych stołach służy również komunikowaniu rzadko widywanym osobom, krewnym i znajomym w różnych krajach, że wszyscy są zdrowi oraz, co niemniej ważne, że przestrzegają zwyczajów. Demonstrowanie zachowań zgodnych z normami i zwyczajami odbywa się za pośrednictwem podawania określonych potraw w odpowiedniej ilości, wznoszenia toastów, odpowiedniego ubioru, języka. Taki przekaz trafiający do osób w różnych lokalizacjach służy utrzymaniu więzi oraz okazaniu wzajemnego szacunku (paciw) wobec odbiorców transmisji lub nagrania.

Towarzyszące pandemii utrudnienia w podróżach, restrykcyjne kontrole na granicach wraz z powszechnym lockdownem sprawiły, że w 2020 roku Wielkanoc obchodzono inaczej niż w ubiegłych latach. Większość Romów pozostała w domach, rezygnując z odwiedzin i przyjmowania gości. Wielkanoc w czasie pandemii Romowie w większości spędzili przy stole, łącząc się z rodziną za pomocą mediów społecznościowych. Spotkania te, w odróżnieniu od lat wcześniejszych, miały charakter zamknięty, nie pojawiły się publiczne relacje, powszechnie znane jako lajfy. 


\section{Podsumowanie i wnioski}

Nasze obserwacje pokazują różnorodne sposoby, w jakie Romowie radzili sobie z utrudnieniami czasu pandemii. Opisane przez nas internetowe aktywności nie stanowią nowego zjawiska i były już obecne w ostatnich latach. Można je również zaobserwować nie tylko wśród Romów. Za sprawą wprowadzonych w marcu i w kwietniu 2020 roku zaleceń „dystansu społecznego" praktyki te nabrały dodatkowego wymiaru. W opisywanym okresie dotyczyły one nie tylko wspólnot transnarodowych. Niezależnie od stanu epidemii, w odniesieniu do romskich rodzin, z którymi pozostajemy w kontakcie (w tym naszych własnych) możemy stwierdzić, że zachodzi tu potrzeba stworzenia niszy i bezpiecznej przestrzeni dla języka i kultury. Internet umożliwia stały kontakt z bliskimi oraz kultywowanie języka i obyczajów, nawet jeżeli jedno i drugie ulega przemianom.

W złożonych i rozproszonych terytorialnie sieciach rodzinnych Internet staje się narzędziem reprodukcji kulturowej, kontroli społecznej i integracji grupy. W transnarodowym kontekście to właśnie Internet umożliwia utrzymywanie tradycji i wzmocnienie więzi społecznych. Łatwość, z jaką media cyfrowe wpasowały się w życie społeczne Romów, sugeruje, że dotykamy tu istotnego elementu tej kultury i możliwości mobilizacji grupowej sprawczości w czasie kryzysu. Spotkania online, „czelendże” i nominacje są nie tylko rozrywką i sposobem spędzania wolnego czasu. Pełnią one również funkcję wspólnotowego rytuału, podczas którego ludzie spotykają się, robią coś razem według określonego wzorca w celu wzmocnienia poczucia wspólnoty. Przed pandemią uczestnicy biesiad i innych zgromadzeń spotykali się w przestrzeni fizycznej, dodatkowo organizując transmisje dla swoich rodzin w innych krajach. Zapośredniczona obecność była więc dodatkiem do całego wydarzenia. W czasie pandemii obecność online stałą się główną platformą ekspresji społeczno-kulturowej. Jej kulturowo-reprodukcyjna rola sprawia, że można odnieść ją do tradycyjnego romanipen, stąd też nasze określenie e-romanipen. Internetowe rytuały odbywały się w czasie niedookreślonego zagrożenia, połączonego $\mathrm{z}$ brakiem możliwości spotkania i tym samym zapewnienia poczucia grupowego bezpieczeństwa, wyrażenia troski i wzmacniania wspólnotowości. Sytuacja ta była więc zagrożeniem nie tylko na poziomie jednostkowym, ale również (lub przede wszystkim) na poziomie grupy i jej przetrwania w wymiarze społecznym (mamy tu na myśli ciągłość grupy, a nie przetrwanie biologiczne). Na co dzień przetrwanie to zapew- 
Ignacy Jóźwiak, Elżbieta Mirga-Wójtowicz, Sonia Styrkacz, Monika Szewczyk

niają spotkania z rodzicami, dziadkami, osobami starszymi i autorytetami w celu przedyskutowania problemów, wymiany informacji i uzgodnienia planów. Niemożność spotkania oznacza więc nie tylko osobisty dyskomfort, ale również zagrożenie dla rodzinnych i innych więzi grupowych. Spontaniczna aktywność o rozrywkowym charakterze w postaci popularnych nomininaw i czelendżos jest sposobem na rozładowanie negatywnych emocji i stresu. Opisana przez nas internetowa aktywność polskich Romów jest przykładem niewątpliwej sprawczości i kreatywności w radzeniu sobie z zewnętrznymi utrudnieniami w funkcjonowaniu grupy i działaniu na rzecz jej spójności.

\section{Podziękowania}

Autor i autorki pragną podziękować Michałowi P. Garapichowi, Kamili Fiałkowskiej i Annie Rosińskiej za uwagi i konsultacje tekstu na jego różnych etapach. Podziękowania należą się również dwóm anonimowym osobom recenzującym, których uwagi pozwoliły nam nadać manuskryptowi jego ostateczną formę. We wstępnym procesie powstawania artykułu swoich komentarzy udzieliły i udzielili nam również koleżanki i koledzy z Zespołu Badań Społeczno-Kulturowych Ośrodka Badań nad Migracjami UW.

\section{BIBLIOGRAFIA:}

Airoldi, M. (2018). Ethnography and the digital fields of social media. International Journal of Social Research Methodology, 21(6), 661-673. DOI: https://doi.org/10.1080/13645579.2018.1465622

Anthias, F.,Yuval-Davis, N. (2005). Racialized boundaries: Race, Nation, Gender, Colour and Class and the Anti-Racist Struggle. London: Routledge.

Baldassar, L., Krzyzowski, L. (2020). Physical, not social distancing: what we can learn from migrants. UWA Social Care and Social Ageing Living Lab News, April 2020. Pozyskano z https://livinglab.com.au/4548-2/

Baldassar, L., Wilding, R. (2020). Migration, Aging, and Digital Kinning: The Role of Distant Care Support Networks in Experiences of Aging Well. The Gerontologist, 60(2), 313-321. DOI: https://doi.org/10.1093/geront/gnz156 
Barth, F. (2004). Grupy i granice etniczne. W: M. Kempny, E. Nowicka (red.), Badanie kultury. Elementy teorii antropologicznej. Kontynuacje (s. 348-377). Warszawa: PWN.

Bartosz, A. (2004). Nie bój się Cygana. Sejny: Pogranicze.

Bielenin-Lenczowska, K. (2015). Spaghetti z ajwarem: translokalna codzienność muzulmanów w Macedonii i we Włoszech. Warszawa: Wydawnictwo Uniwersytetu Warszawskiego.

Boellstorff, T., Nardi, B., Pearce, C., Taylor, T.L. (2012). Ethnography and virtual worlds: A handbook of method. Princeton-Oxford: Princeton University Press.

Caliandro, A. (2018). Digital methods for ethnography: Analytical concepts for ethnographers exploring social media environments. Journal of Contemporary Ethnography, 47(5), 551-578. DOI: https://doi. org/10.1177/0891241617702960

Fiałkowska, K. (2018). Cyber Space: A Refuge for Hegemonic Masculinity among Polish Migrants in the UK. W: Ch. Timmerman, M.L. Fonseca, L. Van Praag, S. Pereira (red.), Gender and Migration. A Gender-Sensitive Approach to Migration Dynamics (s. 95-118). Leuven: Leuven University Press.

Fiałkowska, K., Garapich, M.P., Mirga-Wójtowicz, E. (2018a). Krytyczna analiza naukowej ciszy, czyli dlaczego Romowie migrują (z naszego pola widzenia). Kultura i Spoleczeństwo, 2, 39-67.

Fiałkowska, K., Garapich, M.P., Mirga-Wójtowicz, E. (2018b). Antropologia migracji polskich Romów - wypełnianie luki w badaniach migracyjnych i romologicznych. Studia Romologica 11, 299-336.

Fiałkowska K, Garapich, M.P, Mirga-Wójtowicz, E. (2020). Why Do Roma Migrate (from Our View)? A Critical Analysis of Academic Silence in Polish Scholarship. Critical Romani Studies [w druku].

Gay y Blasco, P., De La Cruz Hernandez, L. (2012). Friendship, anthropology. Anthropology and Humanism, 37(1), 1-14.

Glouftsios, G. (2020). In Heterotopic Times; (Im)mobility, Social-Distancing, and Surveillance. The Coronavirus and Mobility Forum. Pozyskano z https://www.compas.ox.ac.uk/2020/in-heterotopic-times-immobilitysocial-distancing-and-surveillance/

Hajská, M. (2019). The presentation of social status on a social network: The role of Facebook among the Vlax Romani community of Eastern-Slovak origin in Leicester, UK. Romani Studies, 29(2), 123-158. DOI: https://doi. org/10.3828/rs.2019.6 
Ignacy Jóźwiak, Elżbieta Mirga-Wójtowicz, Sonia Styrkacz, Monika Szewczyk

Kapralski, S. (2016). Milczenie, pamięć, tożsamość. Fantazmat „Cygana” i ambiwalencja nowoczesności. Ethos. Kwartalnik Instytutu Jana Pawta II KUL, 29(1), 185-202.

Koper, T. (2018). Strategie adaptacji Romów w Polsce na przykładzie grup Polska Roma i Bergitka Roma. Rozprawa doktorska obroniona w Instytucie Socjologii Uniwersytetu Warszawskiego. Warszawa: Uniwersytet Warszawski.

Koper, T. (2020). Romanipen. O dwóch strategiach „bycia Romem” we współczesnym świecie. Studia Romologica, 13 [w redakcji].

Pink, S., Horst, H., Postill, J., Hjorth, L., Lewis, T., Tacchi, J. (2016). Digital Ethnography. Principles and Practice. Los Angeles - London - New Delhi - Singapore - Washington DC: Sage.

Sheller, M. (2018). Mobility justice: The politics of movement in an age of extremes. London - New York: Verso Books.

Mirga-Kruszelnicka, A. (2018). Challenging Anti-gypsyism in Academia: The Role of Romani Scholars. Critical Romani Studies, 1(1), 8-28.

Mirga, A., Mróz, L. (1994). Cyganie: odmienność i nietolerancja. Warszawa: Wydawnictwo Naukowe PWN.

Nagy, V. (2018). Roma Networks. Ethnic Solidarity in an Internet Age? Intersections. East European Journal of Society and Politics, 4(3), 158-179. DOI: 10.17356/ieejsp.v4i3.440

Okely, J. (1983). The traveller-gypsies. Cambridge-New York: Cambridge University Press.

Okely, J. (2018). Untangling Gypsy ethnic identity, thanks to Barth. W: T.H. Eriksen, M. Jakoubek (red.), Ethnic groups and boundaries today. A legacy of fifty years. London - New York: Routledge.

Osipovič, D. (2013). 'If I get ill, It's onto the plane, and off to Poland'. Use of health care services by polish migrants in London. Central and Eastern European Migration Review, 2(2), 98-114.

Patzer, H. (2018). Napotkanie przedtekstowego. Budowanie wiedzy etnograficznej o migranckich światach troski. Teksty Drugie, 1, 111-126.

Silverman, C. (1988). Negotiating „Gypsiness”: Strategy in Context. Journal of American Folklore, 101(401), 261-275.

Silverman, C. (2018). From Reflexivity to Collaboration: Changing Roles of a Non-Romani Scholar, Activist, and Performer. Critical Romani Studies, 1(2), 76-97.

Szewczyk, M. (2017). Krytyczna analiza „cygańskiego” dyskursu internetowego (społecznościowego). W: D. Piontek, S. Ossowski (red.), Komunikowanie 
społeczne w dobie nowych technologii (s. 217-230). Poznań: Polskie Towarzystwo Komunikacji Społecznej.

Talewicz-Kwiatkowska, J. (2019). Romowie w wirtualnym świecie. W: B. Machul-Telus (red.), Romowie. Warszawa: Wydawnictwo Sejmowe.

Zdrodowska, M. (2014). Zwrot cyfrowy w antropologii? Prace Etnograficzne, 42(4), 279-291. DOI: 10.4467/22999558.PE.14.018.3547 